\title{
PEMBERANTASAN BUTA AKSARA AL-QUR'AN PADA SUKU ANAK DALAM (STUDI KASUS DI DESA DWI KARYA BHAKTI KECAMATAN PELEPAT KABUPATEN BUNGO PROVINSI JAMBI)
}

\author{
ERADICATION OF AL-QUR'AN ILLITERACY ON ANAK DALAM TRIBE \\ (CASE STUDY IN DWI KARYA BHAKTI VILLAGE, PELEPAT SUB-DISTRIK, \\ BUNGO DISTRICT PROVINCE JAMBI)
}

\author{
Muklisin \\ Fakultas Syariah STAI YASNI Muara Bungo \\ Jl. Lintas Sumatera Arah Padang KM.4 Sungai Binjai, Muara Bungo, Provinsi Jambi \\ E-mail: muklisinmukidi@gmail.com
}

DOI: $10.36424 / j p s b . v 5 i 1.22$

Naskah Diterima: 6 April 2019 Naskah Direvisi:25 Aprili 2019 Naskah Disetujui: 01 Juni 2019

\begin{abstract}
Abstrak
Salah satu program yang dicanangkan pemerintah yaitu pemberantasan buta aksara termasuk didalamnya aksara Al-Qur'an. Program pemberantasan buta aksara Al-Qur'an adalah rancangan yang akan dilaksanakan dalam memusnahkan atau membasmi kebutaan sistem penulisan dan cara membaca Al-Qur'an. Bagi Suku Anak Dalam di Desa Dwi Karya Bhakti yang baru masuk dan mengenal Islam, menulis dan membaca Al-Quran tentu menjadi masalah. Tujuan penelitian ini adalah untuk mengetahui metode dan kendala dalam pemberantasan buta aksara Al-Qur'an pada Suku Anak Dalam di Desa Dwi Karya Bhakti. Pada penelitian ini pendekatan yang digunakan adalah penelitian kualitatif deskriptif. Dari penelitian ini diketahui pada Suku Anak Dalam khususnya dalam pemberantasan buta aksara Al-Qur'an, masih belum maksimal karena Suku Anak Dalam mayoritas baru menjadi mualaf, dan jarak tempuh untuk belajar mengaji juga sangat jauh serta kurangnya guru untuk mengajar mengaji masih sangat minim.
\end{abstract}

Kata Kunci: Buta Aksara, Al-Qur'an, Suku Anak Dalam

\begin{abstract}
One of the programs of the government is the eradication of illiteracy, including the script of Al-Qur'an. The Al-Qur'an illiteracy eradication program is a plan that will be implemented to eradicate the blindness of the writing system and how to read the Qur'an. For Suku Anak Dalam in Dwi Karya Bhakti Village who have just entered and known Islam, writing and reading the Qur'an is certainly the problem. The purpose of this study was to find out the methods and constraints in the eradication of Al-Qur'an literacy in the Suku Anak Dalam in the Dwi Karya Bhakti Village. In this study the approach used was descriptive qualitative research. In this study Suku Anak Dalam, especially in the eradication of illiteracy in the Qur'an, is still not maximal because the Tribe of Children in the new majority has become
\end{abstract}


convert, and the distance to study the Qur'an is also very far and the lack of teachers to teach the Qur'an is still very minimal.

Keywords: illiteracy, Al-Qur'an, Suku Anak Dalam

\section{PENDAHULUAN}

Masyarakat Suku Anak Dalam (SAD) adalah masyarakat terasing yang hidup di wilayah Provinsi Jambi. Masyarakat SAD merupakan penduduk yang secara turun temurun menduduki wilayah geografis tertentu, termasuk SAD yang ada di Desa Dwi Karya Bhakti Kecamatan Pelepat Kabupaten Bungo Provinsi Jambi.

Pada dasarnya pemerintah telah memberikan perhatian khusus bagi SAD yang ada di Kabupaten Bungo. Pemerintah berusaha meningkatkan dan memperbaiki kehidupan sosial ekonomi bahkan sampai tingkat pendidikannya. Salah satu aspek utamanya adalah peningkatan pada tahap kesejahteraan mereka dengan cara memberikan pendidikan yang secukupnya kepada masyarakat SAD, memberikan layanan kesehatan, layanan kebutuhan ekonomi dan lain sebagainya.

Khusus dalam pelayanan bidang pendidikan seperti yang tertuang di dalam Undang-undang Nomor 20 Tahun 2003 tentang Sistem Pendidikan Nasional pada Pasal 3 menyatakan bahwa pendidikan nasional berfungsi mengembangkan kemampuan diri dan membentuk watak serta peradaban bangsa yang bermartabat dalam rangka mencerdaskan kehidupan bangsa, bertujuan untuk mengembangkan potensi peserta didik agar menjadi manusia yang beriman dan bertakwa kepada Tuhan Yang Maha Esa, berakhlak mulia, sehat, berilmu, cakap, kreatif, mandiri, dan menjadi warga negara yang demokratis serta bertanggung jawab.

Peningkatan kualitas Sumber Daya Manusia (SDM) merupakan kebutuhan mendesak yang perlu diprioritaskan oleh pemerintah dalam menghadapi era globalisasi dimana perkembangan teknologi dan informasi yang begitu cepat. Pendidikan harus mampu melayani, beradaptasi dan bahkan juga ikut menentukan dunia secara makro yang selalu maju dan cepat. Pendidikan merupakan kebutuhan paling mendasar yang juga menjadi tanggungjawab kita semua, bukan saja 
pemerintah. Sebenarnya apa yang sudah dilakukan oleh pemerintah dalam memenuhi kebutuhan khususnya bidang pendidikan belum sepenuhnya berhasil. Programprogram pembangunan yang bersifat top-down seringkali mengalami kegagalan sehingga mengakibatkan terabaikannya kepentingan masyarakat terasing itu sendiri. Salah satu program dari pemerintah yaitu program pemberantasan buta aksara AlQur'an. Program pemberantasan buta aksara Al-Qur'an adalah rancangan yang akan dilaksanakan dalam memusnahkan atau membasmi kebutaan sistem penulisan dan cara membaca Al-Qur'an.

Program pemberantasan buta aksara ini merupakan program nasional yang sudah dicanangkan sejak tahun 2003 pada masa Presiden Susilo Bambang Yudhoyono. Kebijakan pemerintah pusat yang juga diikuti oleh kebijakan pemerintah di daerah harus sejalan. Salah satu program pelaksanaan pemberantasan buta aksara Al-Qur'an khususnya pada masyarakat SAD banyak mengalami kegagalan, seperti fasilitas tempat belajar mengaji dan juga guru mengaji yang masih sangat minim.

Dalam proses pembelajaran pemberantasan buta aksara Al-Qur'an masyarakat Suku Anak Dalam (SAD) di Desa Dwi Karya Bhakti Kecamatan Pelepat, sebenarnya sudah dilaksanakan. Salah satu metode yang biasa dipakai secara umum untuk belajar mengaji adalah dengan menggunakan metode Iqro'. Pengajaran dengan metode Iqro' yang diterapkan juga mengalami kesulitan dikarenakan cara bicara yang berbeda dengan bahasa yang mereka miliki. Selain itu yang menjadi kendala dan masalah adalah dari segi kekurangan tempat mengaji dan juga jarak tempuh yang jauh dari pemukiman warga SAD serta jumlah guru untuk mengajarkan baca tulis AlQur'an yang masih kurang.

Sementara hambatan yang dihadapi dari segi minimnya guru mengaji di masyarakat SAD disana akan memperlambat proses pemberantasan buta aksara AlQur'an. Sehingga keadaan itu akan membawa implikasi lambannya program pemerintah. Tantangan dan hambatan yang terjadi pada masyarakat SAD di Desa Dwi Karya Bhakti maka perlu adanya kerjasama yang baik antara aparatur desa dengan aparatur pemerintah di daerah. Seperti yang terjadi pada masyarakat SAD 
tersebut harus saling mendukung satu sama lainnya. Dalam program pemberantasan buta aksara Al-Qur'an yang telah dicanangkan oleh pemerintah, ketika metode pembelajarannya kurang pas juga akan menjadi kendala tersendiri.

Tantangan dan hambatan yang dihadapi di dalam menjalankan program pemberantasan buta aksara Al-Qur'an di masyarakat SAD secara garis besar bisa dibagi menjadi dua bentuk, yaitu pelaksanaan di lapangan dan hambatan dari masyarakat SAD itu sendiri. Hal yang perlu dilihat dalam tantangan dan hambatan tersebut, yaitu kurangnya minat belajar masyarakat SAD. Sebenarnya ini bukanlah hambatan yang dialami oleh pemerintah, karena tugas pemerintah harus bisa menciptakan metode pembelajaran yang menarik sehingga diharapkan bisa menarik minat baca dan menulis Al-Qur'an bagi masyarakat SAD disana.

Berdasarkan kenyataan di atas, artikel ini berusaha melihat pembangunan masyarakat Suku Anak Dalam di Desa Dwi Karya Bhakti Kecamatan Pelepat Kabupaten Bungo Provinsi Jambi dalam program pemberantasan buta aksara AlQur'an.

\section{METODE PENELITIAN}

Penelitian ini merupakan penelitian lapangan (field research) yang bersifat deskriptif kualitatif, yaitu penelitian untuk memahami fenomena tentang apa yang dialami oleh objek penelitian, misalnya prilaku, persepsi, motivasi dan tindakan secara holistik dengan cara dan deskriptif bentuk kata-kata dan bahasa dalam konteks khusus yang alamiah. Menurut Faisal (1990: 32), dalam penelitian kualitatif terdapat proses yang berbentuk siklus, proses yang berbentuk siklus tersebut dapat diidentifikasi adanya tiga tahapan yang berlangsung secara berulang-ulang, yaitu Pertama, eksplorasi yang meluas dan menyeluruh yang biasanya masih bergerak pada tahap permukaan. Kedua, eksplorasi secara terfokus atau terseleksi guna mencapai tingkat kedalaman dan kerincian tertentu. Ketiga, pengecekan atau konfirmasi hasil temuan penelitian (Faisal, 1990: 34). 
Penelitian ini dimaksudkan untuk memahami prilaku manusia berdasarkan kerangka acuan penelitian, yakni tentang pemberantasan buta aksara Al-Qur'an pada masyarakat SAD di Desa Dwi Karya Bhakti Kecamatan Pelepat Kabupaten Bungo. Studi kualitatif dengan pendekatan naturalistic menuntut pengumpulan data pada setting yang wajar (natural setting) inkuiri naturalistik tidak mewajibkan peneliti membentuk konsepsi-konsepsi atau teori tertentu mengenai lapangan penelitiannya sebelumnya, sebaliknya peneliti dapat mendekati lapangan penelitiannya dengan pikiran yang murni tanpa ada tendensius pribadi dan memperkenankan interprestasi yang muncul dari atau dipengaruhi oleh peristiwa-peristiwa nyata, bukan sebaliknya (Moleong, 2002: 3). Sifat naturalistik pada umumnya menggunakan analisis induktif murni, karena dengan cara tersebut konteksnya akan lebih mudah untuk dideskripsikan, konteks yang natural merupakan kebulatan menyeluruh. Satu fenomena hanya dapat ditangkap maknanya dalam keseluruhan dan merupakan suatu bentuk hasil peran timbal balik, bukan sekedar hubungan linier saja (Muhadjir, 1996: 108).

\section{PEMBAHASAN}

\section{Historis Masyarakat Suku Anak Dalam di Desa Dwi Karya Bhakti}

Desa Dwi Karya Bhakti Kecamatan Pelepat Kabupaten Bungo merupakan salah satu desa yang induk desanya terletak di Dusun Pasir Putih Kecamatan Pelepat Kabupaten Bungo. Sejarah berdirinya Desa Dwi Karya Bhakti dimulai tahun 1955. Sebelumnya bernama Desa Pasir Putih yang penduduk aslinya adalah Suku Anak Dalam (SAD) atau dikenal juga dengan istilah Suku Kubu atau Suku Rimba. Pada saat itu Suku Anak Dalam (SAD) berada di dalam rimba seluas 6,8 ha. Pada tahun 1968 ada penambahan satu kampung yang diberi nama Talang Tembang, kemudian pada tahun 1975 adalagi penambahan desa yang bergabung ke Dusun Pasir Putih yaitu kampung Lintas Jaya. Pada tahun 1989 terjadi pengembangan desa dengan menggabungkan beberapa desa yaitu Pasir Putih, Talang Tembang, Lintas Jaya, 
Sungai Dingin dan Bukit Baru menjadi Desa Dwi Karya Bhakti (Suwardi, Wawancara 15 November 2018, Dwi Karya Bhakti).

Sejarah perkampungan Suku Anak Dalam (SAD) yang berada di Desa Dwi Karya Bhakti yaitu dimana sebelum adanya Desa Dwi Karya Bhakti terlebih dahulu Suku Anak Dalam sudah menghuni pemukiman tersebut. Mereka mulanya berasal dari Sungai Kelukup atau Lubuk Payung. Nama Kampung Sungai Kelukup sendiri yang ditinggali oleh Suku Anak Dalam adalah nama yang dibuat sendiri oleh Suku Anak Dalam bersama Tumenggung berdasarkan kesepakatan bersama. Tumenggung adalah gelar tertinggi bagi kepala suku di Suku Anak Dalam. Sejak tahun 1989, Kampung Sungai Kelukup sudah tetap menjadi Desa Dwi Karya Bhakti yang dipimpin oleh seorang Tumenggung. Seiring dengan perkembangan zaman, pemukiman Suku Anak Dalam (SAD) di Desa Dwi Karya Bhakti oleh Dinas Sosial yang sudah menetap dan memiliki pemukiman dengan luas 6,8 $\mathrm{Ha}$, diganti namanya menjadi Komunitas Adat Terpencil (KAT).

Saat ini jumlah penduduk Suku Anak Dalam (SAD) di Kampung Sungai Kelukup berjumlah 128 jiwa, dengan jumlah laki-laki 71 jiwa dan perempuan 57 jiwa. Oleh Kementerian Sosial, Komunitas Adat Terpencil (KAT) sudah memiliki struktur organisasi yang resmi dimana KAT dipimpin oleh seorang Tumenggung dan juga ada bagian yang mengurusi Pencerai, Penghulu dan Mbah Adat. Penduduk Suku Anak Dalam (SAD) di Kampung Sungai Kelukup mayoritas sudah memeluk agama Islam, selebihnya masih menganut kepercayaan masing-masing. Dimana dari 128 jiwa yang sudah beragama Islam berjumlah 85 dan 43 masih menganut kepercayaannya. Mayoritas penduduk Suku Anak Dalam (SAD) disana bermata pencarian berburu ke dalam hutan dan selebihnya bertani serta berternak. (Suwardi, Wawancara 15 November 2018, Dwi Karya Bhakti).

\section{Program Pemberantasan Buta Aksara Al-Qur'an}

Kata program berarti rancangan atas sesuatu yang akan dikerjakan, kata pemberantasan berarti proses atau cara dan tindakan melenyapkan sesuatu, sedangkan 
buta aksara Al-Qur'an berarti tidak memahami cara membaca Al-Qur'an. Jadi program pemberantasan buta aksara Al-Qur'an adalah rancangan yang akan dilaksanakan dalam memusnahkan atau membasmi kebutaan sistem penulisan dan cara membaca Al-Qur'an. Kriteria buta aksara Al-Qur'an adalah tidak bisa membunyikan atau membaca aksara Al-Qur'an dengan benar serta tidak dapat menggunakan tanda-tanda atau simbol yang biasa dipergunakan dalam kaidah penulisan ayat-ayat Al-Qur'an dengan benar.

Pengertian buta aksara Al-Qur'an adalah tidak mampu untuk membaca dan menulis aksara yang membangun kalimat-kalimat dalam setiap ayat-ayat Al-Quran yang dikhawatirkan tidak bisa memahami makna yang terkandung dalam setiap ayat sebagai pedoman hidup umat Islam (Yasin, 1997: 381). Program pemberantasan buta aksara ini merupakan program nasional yang dicanangkan sejak tahun 2003. Kemudian pada tahun 2005, Presiden Susilo Bambang Yudhoyono mencanangkan program percepatan pemberantasan buta aksara yang rencananya tuntas pada tahun 2009. Seluruh daerah seperti Provinsi Jambi, turut mencanangkan program tersebut dengan menyusun sasaran dan tentu saja beserta anggarannya. Untuk mengatasi permasalahan buta aksara ini, pemerintah pusat telah mengeluarkan beberapa landasan hukum sekaligus sebagai dasar kebijakan dalam memberantas buta aksara yaitu :

a) Instruksi Presiden nomor 5 Tahun 2006 tentang Gerakan Nasional Percepatan Penuntasan Wajib Belajar Diknas 9 Tahun dan pemberantasan buta aksara (termasuk di dalamnya Aksara Al-Qur'an).

b) Keputusan bersama Mendiknas, Mendagri, dan Meneg PP tentang percepatan Pemberantasan Buta Aksara Perempuan.

c) Kerjasama Mendiknas dengan berbagai organisasi sosial kemasyarakatan di antaranya : KPK Pusat, Muslimat NU, Aisyiyah, Kowani, dan Wanita Islam.

d) Keputusan Menko Kesra No. 22 Tahun 2006 tentang Tim Koordinasi Gerakan Nasional Percepatan Penuntasan Wajar Dikdas dan Pemberantasan Buta Aksara. 
e) Keputusan Mendiknas No. 35 Tahun 2006 tentang pembentukan Tim Pelaksana Gerakan Nasional Percepatan Penuntasan Wajar Dikdas dan pemberantasan Buta Aksara dan pembentukan sekretariatnya.

f) Keputusan Dirjen Pendidikan Luar Sekolah nomor. kep-82/e/ms/2007 tentang pembentukan kelompok kerja pemberantasan Buta Aksara (Sujana, 2002: 910)

Program pemberantasan buta aksara Al-Qur'an selama ini sering berjalan pasang surut. Hal ini disebabkan karena berbagai hal diantaranya :

a) Kesadaran akan pentingnya tingkat keaksaraan Al-Qur'an oleh penduduk belum menjadi kesadaran kolektif.

b) Rendahnya tingkat perekonomian keluarga sehingga perhatian keluarga masih terfokus pada ekonomi belum kepada pendidikan termasuk pemahaman terhadap Al-Qur'an.

c) Sosial budaya yang masih sering memandang pendidikan agama Islam sebagai pendidikan dinomor duakan.

d) Rendahnya perhatian dari penyelenggara negara (pemerintah dan DPR).

e) Jarang ada anggaran yang disediakan untuk program pendidikan keaksaraan Al-Qur'an, jika dibandingkan dengan program-program dalam satu faktor maupun luar faktor yang sangat terkait dengan program ini seperti faktor kesehatan, keluarga berencana dan ketenagakerjaan (Sujana: 2002: 11).

Program pemberantasan buta aksara Al-Qur'an yang dilakukan pada Suku Anak Dalam di Desa Dwi Karya Bhakti saat ini masih belum berjalan dengan optimal. Hal ini dapat dilihat dari berbagai persoalan yang timbul dalam proses pelaksanaannya, termasuk kebijakan pemerintah yang masih belum sepenuhnya memberikan program khusus kepada Suku Anak Dalam (SAD) di Desa Dwi Karya Bhakti.

\section{Hambatan dan Halangan yang Dihadapi Pemerintah dalam Pemberantasan Buta Aksara Al-Qur'an}


Hambatan dan halangan yang dihadapi pemerintah dalam pemberantasan buta aksara Al-Qur'an bagi Suku Anak Dalam (SAD) di Desa Dwi Karya Bhakti adalah sebagai berikut :

\section{Jauhnya Tempat Tinggal Pengajar}

Suku Anak Dalam (SAD) di Desa Dwi Karya Bhakti khususnya kampung Sungai Kelukup Kecamatan Pelepat ini terdapat 128 jiwa Suku Anak Dalam dan 84 diantaranya sudah memeluk agama Islam sementara tenaga pengajar yang bersedia tinggal di pemukiman Suku Anak Dalam (SAD) hanya 1 orang. Sehingga tidak optimal 1 orang mengajar 84 orang, dengan kata lain tidak sebanding antara peserta didik dengan tenaga pengajarnya. Sementara ada di Kampung Pasir Putih tempat belajar yaitu sekolah pintar yang jaraknya cukup jauh. Jarak yang harus ditempuh oleh pengajar kurang lebih $45 \mathrm{~km}$ atau kurang lebih 1 jam perjalanan dengan kondisi jalan tanah dan berlumpur. Di sekolah pintar tersebut ada relawan yang diutus pemerintah untuk mendampingi program pemberantasan buta aksara Al-Qur'an selama 3 tahun yaitu LSM Pundi Sumatera. Akan tetapi karena jauhnya tempat tinggal pengajar menyebabkan kurang optimalnya proses pendampingan bagi Suku Anak Dalam (SAD) di Desa Dwi Karya Bhakti (Elma, Wawancara 17 November 2018, Dwi Karya Bhakti).

\section{Jauhnya Jarak Tempuh}

Perlu diketahui bahwa akses jalan menuju ke pemukiman Suku Anak Dalam (SAD) di Desa Dwi Karya Bhakti kurang lebih 45 km masuk ke dalam dari pemukiman warga. Selain jarak tempuh yang jauh, jalan menuju ke tempat pemukiman Suku Anak Dalam juga banyak yang rusak berlubang dan berlumpur. Apalagi kalau musim penghujan, maka akses jalan menuju kesana tidak bisa dilalui dengan kendaraan roda empat, kecuali mobil yang roda tinggi atau kendaraan lapangan. Selain jalan yang rusak apabila hujan maka satu-satunya jalan ditempuh harus berjalan kaki menuju ke pemukiman Suku Anak Dalam (SAD). Faktor jarak tempuh yang jauh juga menjadi kendala 
dalam pelaksanaan program pemberantasan buta aksara Al-Qur'an. Selain jalan yang rusak juga sebenarnya ada jalan alternatif tetapi agak jauh yaitu harus melewati hutan kalau melewati Kampung Pasir Putih.

\section{Kurangnya Minat Belajar}

Masyarakat Suku Anak Dalam (SAD) di Desa Dwi Karya Bhakti Kampung Sungai Kelukup berjumlah 128 jiwa dan terbagi menjadi 40 kepala keluarga, sebagian besar mereka masih memakai tradisi berburu ke hutan atau tradisi "melangun" sehingga perhatian terhadap pendidikan masih sangat minim sekali. Suku Anak Dalam (SAD) tidak bisa dipaksa untuk belajar. Sehingga guru mengaji di sana mengajar hanya kalau Suku Anak Dalam mau belajar saja (Elma, Wawancara 17 November 2018, Dwi Karya Bhakti).

Kurangnya minat belajar Suku Anak Dalam (SAD) di Desa Dwi Karya Bhakti juga menjadi kendala bagi program pemberantasan buta aksara AlQur'an. Anak-anak disana umumnya tidak mau dipaksakan untuk belajar. Selain itu juga bimbingan dari orangtua Suku Anak Dalam juga kurang ada sehingga anak-anak lebih suka ikut orangtuanya berburu atau bermain.

\section{Upaya yang Dilakukan Pemerintah dalam Pemberantasan Buta Aksara Al- Qur'an}

Untuk mengatasi masalah-masalah dalam pelaksanaan program pemberantasan buta aksara Al-Qur'an pada masyarakat Suku Anak Dalam (SAD) di Desa Dwi Karya Bhakti, ada beberapa hal yang bisa dilakukan:

1) Menjalin Kerjasama antara Kepala Direktorat Komunitas Adat Terpencil (KAT) dengan Pendamping Lokal.

Untuk meningkatkan kualitas bimbingan kepada Suku Anak Dalam (SAD) di Desa Dwi Karya Bhakti perlu adanya pendampingan lokal. Mengingat jauhnya tempat tinggal pengajar dari Kampung Sungai Kelukup. Pendamping lokal yaitu dengan penambahan tenaga pengajar pada Suku Anak Dalam (SAD) di Desa Dwi Karya Bhakti. Hal tersebut diungkapkan oleh 
salah seorang tenaga pengajar yang ada disana bahwa untuk kelancaran program pemberantasan buta aksara Al-Qur'an selaku Komunitas Adat Terpencil (KAT) harus berusaha meningkatkan bimbingan kepada khususnya orangtua Suku Anak Dalam supaya program ini berdaya guna dan berhasil memberantas buta aksara Al-Qur'an. Orangtua harus giat dalam membimbing anaknya untuk terus belajar Al-Qur'an dan tidak banyak lagi mengikuti orangtuanya ke dalam hutan untuk berburu binatang (Elma, Wawancara 17 November 2018, Dwi Karya Bhakti).

Selain menjalin kerjasama antara Komunitas Adat Terpencil (KAT) dengan pendamping lokal, maka pemerintah melalui kepala desa juga bisa turut mensukseskan program pemberantasan buta aksara Al-Qur'an dengan cara memberikan bantuan berupa buku pelajaran agama dan buku membaca Al-Qur'an metode Iqro' agar kegiatan proses belajar mengajar berlangsung dengan baik sehingga tidak ada lagi Suku Anak Dalam (SAD) di Desa Dwi Karya Bhakti yang buta aksara Al-Qur'an.

Sebenarnya dalam hal ini, dari Kementerian Sosial dan sejumlah LSM seperti LSM Pundi Sumatera bisa melakukan bimbingan kepada para orangtua Suku Anak Dalam untuk lebih giat lagi menyuruh anaknya untuk belajar, khususnya pada program pemberantasan buta aksara Al-Qur'an. Kegiatan bimbingan ini bisa dilakukan secara berkala, misalnya dalam seminggu sekali atau sebulan dua kali. Dengan harapan semua orangtua yang memiliki anak bisa terus semangat dan termotivasi belajar membaca dan menulis Al-Qur'an. Kenyataan dimanapun berada perkampungan atau kawasan masyarakat terasing jauh dan sukar didatangi oleh pihak terkait dan termasuk Suku Anak Dalam (SAD) di Desa Dwi Karya Bhakti yang masih minim perhatian dari pemerintah.

Proses pendampingan harus terus dilaksanakan guna memberikan perhatian dari pihak-pihak terkait seperti pemerintah melalui kepala desa, pihak Dinas Sosial atau pihak LSM Pundi Sumatera. Dalam pendampingan 
tersebut Kementerian Sosial, LSM dan pihak pemerintah dapat merumuskan beberapa hambatan yang dihadapinya selama pelaksanaan program pemberantasan buta aksara Al-Qur'an.

Pertama, pada tingkat lokal, persepsi yang berbeda dalam pemberdayaan Komunitas Adat Terpencil (KAT), seperti dalam penetapan sasaran yang dituju harus sesuai dengan kondisi yang ada di lapangan. Sehingga bisa optimal dalam pemberantasan buta aksara Al-Qur'an.

2) Memperbaiki Akses Jalan

Selain hambatan tersebut di atas, ada juga yang menjadi faktor penyebab kurang optimalnya program pemberantasan buta aksara Al-Qur'an pada Suku Anak Dalam (SAD) di Desa Dwi Karya Bhakti. Diantara faktor penghambat adalah adanya akses jalan yang buruk. Salah satu faktor penyebab akses jalan yang buruk pada Suku Anak Dalam (SAD) di Desa Dwi Karya Bhakti adalah faktor anggaran dari pemerintah dalam membangun infrastruktur jalan.

Saat ini yang baru bisa dilakukan oleh pihak kepala Desa Dwi Karya Bhakti adalah mengajak kepala kampung Suku Anak Dalam untuk bersamasama memperbaiki jalan yang biasa mereka lewati untuk akses keluar masuk Suku Anak Dalam (SAD) di Desa Dwi Karya Bhakti. Akses jalan yang masih memprihatinkan menuju Kampung Sungai Kelukup dan jauh dari perkampungan kegiatan belajarpun menjadi terganggu. Akses lembaga pendidikan sekolah dasar dan tempat belajar mengaji sangat jauh dari Kampung Sungai Kelukup yaitu harus menempuh perjalanan puluhan kilo meter sehingga menjadi kendala. Apalagi kalau pas kondisi hujan maka jalan tidak bisa dilewati oleh kendaraan melainkan harus berjalan kaki.

Salah satu solusi dari pemerintah yaitu harus bisa menganggarkan untuk akses jalan menuju ke perkampungan Suku Anak Dalam (SAD) di Desa Dwi Karya Bhakti. Selain itu juga bisa dengan mengusulkan kepada pihak 
terkait seperti Dinas Sosial untuk mengatasi jarak tempuh yang jauh ketika Suku Anak Dalam mau pergi belajar mengaji maka alangkah baiknya kalau dicari orang yang mau mengajar di pemukiman Suku Anak Dalam (SAD) di Desa Dwi Karya Bhakti khususnya Kampung Sungai Kelukup. Jadi anak-anak yang ingin belajar tidak harus jauh-jauh pergi ke kampung tetangga. Saat ini memang sudah ada pengajarnya akan tetapi baru ada 1 (satu) orang sementara yang mau diajar sebanyak 84 orang, jadi tidak sebanding. Sehingga apa yang diharapkan oleh pemerintah melalui program pemberantasan buta aksara AlQur'an pada Suku Anak Dalam (SAD) di Desa Dwi Karya Bhakti akan terlaksana dengan baik dan optimal.

Pada tingkat nasional, ada beberapa masalah yang dihadapi dalam pemberdayaan Komunitas Adat Terpencil (KAT) yaitu kurangnya keprihatinan masyarakat luar dalam pembangunan masyarakat terasing. Selain itu juga di beberapa daerah, untuk menangani masalah masyarakat terpencil tidak menjadi fokus daerah. Itu karena besarnya biaya yang diperlukan untuk pembangunan sosial masyarakat tersebut (Departemen Sosial RI, 2004: 6-10).

3) Memberi Motivasi Belajar Pada Suku Anak Dalam

Peran Dinas Sosial, pemerintah dan LSM Pundi Sumatera dalam memberikan motivasi belajar pada Suku Anak Dalam (SAD) di Desa Dwi Karya Bhakti sangatlah penting. Dalam hal ini yang sudah dilakukan oleh kepala desa Dwi Karya Bhakti adalah menjalin silaturahmi dengan masyarakat Suku Anak Dalam sehingga mereka merasa nyaman dan merasa diperhatikan.

Masalah pembangunan kesejahteraan atau peningkatan kualitas hidup masyarakat terasing, terutama pada masyarakat Suku Anak Dalam (SAD), tidak dapat dilepaskan dari usaha yang serius dari pemerintah. Di Jambi, tepatnya di Desa Nyogan, kesejahteraan hidup masyarakat belum tercapai. Bahwasannya hasil penelitian yang dilakukan pada masyarakat di Sungai Segandi, Nyogan adalah 
masyarakat yang miskin (Kusnadi, 2010: 343). Kurangnya kualitas hidup masyarakat Suku Anak Dalam (SAD) di Desa Nyogan di masa pembangunan pada dasarnya karena kesalahan pemerintah yang terlalu cepat mengubah cara hidup masyarakat tanpa melihat adat dan kebiasaan serta tata cara kehidupan masyarakat Suku Anak Dalam (SAD) itu sendiri. Kemudian pemerintah terlalu menyamaratakan semua masyarakat terasing. Padahal, setiap masyarakat memiliki segi kehidupan masingmasing (Kusnadi, 2010: 343).

Konsep pembangunan diartikan sebagai suatu transformasi secara "menyeluruh" masyarakat tradisional atau masyarakat pramodern menjadi masyarakat yang bercorak teknologi serta organisasi sosialnya berkaitan seperti yang terdapat di negara-negara maju (Soekanto, 2001: 47). Konsep ini sering dinamakan dengan modenisasi, yakni pergantian teknik produksi daripada cara tradisional ke cara-cara modern yang tertampung dalam pengertian revolusi industri.

Pada Suku Anak Dalam (SAD) di Desa Dwi Karya Bhakti khususnya Kampung Sungai Kelukup terkait peningkatan kualitas hidup terutama dalam hal masalah pendidikan kurang mendapatkan penanganan secara khusus oleh pemerintah sehingga program pemberantasan buta aksara Al-Qur'an belum berjalan secara optimal. Selain pembangunan dalam bidang pendidikan, masalah perekonomian juga akan berimbas kepada tingkat pendidikannya seperti halnya Suku Anak Dalam (SAD) lebih suka berburu untuk memenuhi kebutuhannya secara ekonomi dari pada belajar. Oleh karenanya keberhasilan pembangunan ekonomi secara otomatis akan berpengaruh kepada kehidupan masyarakatnya.

Untuk mengatasi kurangnya semangat belajar pada Suku Anak Dalam (SAD) di Desa Dwi Karya Bhakti khususnya Kampung Sungai Kelukup, maka dalam hal ini Kepala Desa dengan perangkat desa lainnya seperti dari Kantor Urusan Agama (KUA) memberikan bantuan buku-buku belajar, alat tulis, dan menyediakan fasilitas belajar dengan harapan akan mampu membuat Suku Anak Dalam (SAD) tambah semakin semangat untuk belajar. Selain itu juga bagi Suku Anak Dalam (SAD) sering diberikan hadiah berupa alat tulis belajar, makanan dalam bentuk jajanan 
sehingga anak-anak menjadi semangat untuk belajar. Selain pemberian fasilitas belajar tersebut kepala desa juga memberikan nasehat dan juga motivasi kepada Suku Anak Dalam tentang pentingnya mempelajari Al-Qur'an.

Demikianlah pelaksanaan program pemberantasan buta aksara Al-Qur'an pada Suku Anak Dalam (SAD) di Desa Dwi Karya Bhakti khususnya Kampung Sungai Kelukup walaupun hasilnya belum maksimal.Disebabkan oleh beberapa faktor kendala baik yang datang secara internal dari Suku Anak Dalam (SAD) sendiri dan juga secara eksternal. Meski demikian, tidak dapat dipungkiri bahwa pemberantasan buta aksara Al-Qur'an tidaklah mudah dilaksanakan, cukup banyak kendala dan tentunya pasti jelas ada manfaatnya bagi Suku Anak Dalam (SAD) di Desa Dwi Karya Bhakti.

\section{PENUTUP}

Masyarakat Suku Anak Dalam (SAD) di Desa Dwi Karya Bhakti khususnya Kampung Sungai Kelukup sudah menempati kampung tersebut sejak tahun 1955, dan telah terjadi berbagai bentuk pemerintahan dari penggabungan beberapa kampung menjadi Desa Dwi Karya Bhakti. Jumlah masyarakat Suku Anak Dalam di Kampung Sungai Kelukup adalah 128 jiwa. Pada umumnya mata pencariannya adalah berburu ke dalam hutan dan sebagian kecil bertani. Mayoritas masyarakat Suku Anak Dalam (SAD) di Desa Dwi Karya Bhakti khususnya Kampung Sungai Kelukup sudah menganut agama Islam, dan masih ada sebagian kecil yang menganut kepercayaannya.

Pelaksanaan program pemberantasan buta aksara Al-Qur'an pada Suku Anak Dalam (SAD) di Desa Dwi Karya Bhakti khususnya Kampung Sungai Kelukup, masih belum maksimal yang disebabkan oleh beberapa kendala dan kurangnya minat untuk belajar. Jumlah pengajar yang minim dan jarak tempuh tempat belajar dengan tempat pemukiman yang jauh juga menjadi kendala dalam program pemberantasan buta aksara Al-Qur'an. Walaupun beberapa upaya sudah dilakukan oleh Kepala Desa, Dinas Sosial, dan LSM Pundi Sumatera dalam melaksanakan program 
pemberantasan buta aksara Al-Qur'an diantaranya dengan memberikan fasilitas belajar seperti buku-buku agama, buku Iqro', dan alat tulis sekolah. Namun, dalam pelaksanaannya masih belum maksimal yang disebabkan oleh faktor internal dan faktor eksternal itu sendiri.

Dari kesimpulan di atas peneliti memberikan saran-saran yaitu hendaknya perangkat desa dan pengajar mengaji senantiasa memberikan motivasi dan semangat kepada Suku Anak Dalam (SAD) di Desa Dwi Karya Bhakti, khususnya Kampung Sungai Kelukup dengan memberikan hadiah-hadiah sehingga Suku Anak Dalam menjadi semangat terus untuk belajar membaca dan menulis Al-Qur'an sehingga dapat dirasakan manfaatnya secara langsung oleh Suku Anak Dalam (SAD). Selain itu kepada pemerintah terutama Dinas Sosial dan Kementerian Agama agar senantiasa memberikan bimbingan kepada setiap Suku Anak Dalam (SAD) dalam hal kesadaran akan pentingnya mempelajari Al-Qur'an dalam kehidupan sehari-hari.

\section{DAFTAR PUSTAKA}

Departemen Pendidikan RI. 2003. Undang-Undang Sistem Pendidikan Nasional. Jakarta: Depdiknas RI

Departemen Sosial RI. 2004. Membangun Jaringan Kerja Sama Pemberdayaan Komunitas Adat Terpencil. Jakarta: Direktorat Pemberdayaan Komunitas Adat Terpencil Departemen Sosial RI

Faisal, Sanafia, 1990, Penelitian Kualitatif: Dasar-Dasar Aplikasi, Malang: Yayasan Asih Asuh

Hamzah, Sirajudi, 2002, Teknik Penggunaan Metode Iqro' (Cara Belajar Cepat Membaca Al-Qur'an), Surabaya: Amanah

Kusnadi, 2010, Pembangunan Sosial Masyarakat Terasing di Era Otonomi Daerah: Studi Kasus Masyarakat Suku Anak Dalam di Muaro Jambi, Jambi: Jurnal Media Akademika UIN Sulthan Thaha Saifuddin Jambi

Moleong, Lexy J, 2002, Metode Penelitian Kualitatif, Bandung: Remaja Rosda Karya offset

Muhadjir, Noeng, 1996, Metodologi Penelitian Kualitataif, Yogyakarta: Rake Sarasin Soekanto, Soejono, 2001, Sosiologi: Suatu Pengantar, Jakarta: Rajawali Press

Sujana, Nana, 2002, Efektifitas Metode Iqro' dalam Memberantas Buta Aksara AlQur'an pada Ibu-ibu Rumah Tangga, Yogyakarta: UII Yogyakarta

Yasin, Sulchan, 1997, Kamus Lengkap Bahasa Indonesia, Surabaya: Amanah 